\title{
The Application of Data-Driven Learning in Business English Teaching for MBA Students in China: A Critical Assessment
}

\author{
Jing Shi ${ }^{1}$ \\ ${ }^{1}$ School of English for International Business, Guangdong University of Foreign Studies, Guangzhou, \\ Guangdong, China \\ Correspondence: Jing Shi, School of English for International Business, Guangdong University of Foreign \\ Studies, Guangzhou, Guangdong, 510420, China. E-mail: sj@oamail.gdufs.edu.cn
}

Received: October 20, 2012 Accepted: January 4, 2013 Online Published: January 25, 2013

doi:10.5539/ijel.v3n1p26

URL: http://dx.doi.org/10.5539/ijel.v3n1p26

This essay belongs to the research project “'Data-Driven Learning' in MBA English teaching” (Project Code: 12Q21) financed by Guangdong University of Foreign Studies; and it is also financed by the Sixth Session of "China Foreign Language Education Fund" of China National Research Center for Foreign Language Education (Program Code: ZGWYJYJJ2012A37).

\begin{abstract}
This paper is aimed at laying foundation for the application of Data-Driven Learning (DDL) in the Master of Business Administration (MBA) English teaching and furthers its development and improvement in different contexts. Therefore, the paper attempts to illustrate the pilot application of an innovative teaching method, DDL, in Business English (BE) teaching for the MBA program. The survey, by using questionnaire and analysis of the data, reveals the positive effects of the DDL application in the MBA program and some disadvantageous aspects which require improvement.
\end{abstract}

Keywords: Data-Driven Learning (DDL), Business English (BE), Master of Business Administration (MBA) program

\section{Introduction}

Business English (BE) is booming in China with China's economy growing dramatically and its becoming more integrated into the international community. In most MBA programs in China, the Comprehensive Business English Course (CBEC) is a prescribed general education course for MBA students to practice the all four skills of BE: listening, speaking, reading, and writing in the business context. In a non-English speaking country like China, MBA students do not have many opportunities practicing BE outside of class. They usually acquire vocabulary, study sentence structures and grammatical rules, and practice the four skills, only in the CBEC.

The new version of the syllabus for MBA programs in China, issued by China National MBA Education Supervisory Committee (2011), attaches great emphasis on the internationalization of the MBA program in China. Constructing effective BE course is a vital step for MBA program to go internationalized (China National MBA Education Supervisory Committee, 2011). However, it illustrates the new requirements for the courses in MBA programs, except for the BE course. The lack of detailed requirements for the BE course results in problematic construction and organization of the course. Textbooks are not tailor-made to satisfy the needs of MBA students. The lessons are predictable and quite monotonous-teachers illustrate language points, give students exercises to work on, and administer tests. Therefore, teachers do most of the talking while students listen, take notes, or give short and simple responses. Students are not motivated to perform well in the CBEC because they have already had extensive exposure to this type of teacher-centered and spoon-fed approach to language instruction.

Considering the syllabus of the postgraduate English course for Non-English Majors (2001), I believe an effective BE course for MBA students should be specially-designed to satisfy the needs of them and enables them to be qualified to use BE in the work field. Therefore, the course should be interactive and the teaching materials should be authentic. In this article, I describe some activities based on Data-Driven Learning (DDL), which can turn a dull and dry lesson plan into an inductive and self-directed language teaching and learning 
practice, emphasizing authenticity and interaction.

\section{Theoretical Framework}

BE teaching for MBA students in China has a long tradition of instructivist-based pedagogy which relies on lectures and memorization. The instructivist-based approaches fail to trigger MBA students' interest in BE learning and falls short of MBA students' expectations. Therefore, I intend to reform this approach.

Constructivism has been regarded as a philosophy and a theory of communication and, in recent decades it has emerged as a dominant paradigm in education (Kaufman, 2004). Constructivism in education originates from notions of cognitive and social constructivism (Schcolnik et al, 2006; Kaufman, 2004). The former is rooted in the work of Piaget (1970; Piaget and Inhelder 1971) and focuses on cognitive development and individual construction of knowledge; the latter sheds light on social construction of knowledge and is grounded in the work of Vygotsky (1986). In fact, DDL is based on both cognitive and social constructivism.

DDL, based on Constructivism, is the application of corpus linguistics in English teaching and learning. The application of DDL in BE teaching for MBA students has three advantages: First, corpus can provide abundant sources of authentic language. Most BE teachers in MBA programs in China do not have enough work experience in the business field, and they have to depend on reliable source of BE in order to manage this course well. Second, BE is changing dramatically with a large number of nascent jargons. Corpus can help teachers keep abreast of changes in BE. Third, using corpus in BE teaching can bring the class more fun and students will be more involved in learning.

\section{The Application of DDL}

\subsection{Activity 1: Vocabulary Teaching}

The conventional method of vocabulary teaching and learning in CBEC class is usually of the Present-Practice-Produce (PPP) mode: teachers present the pronunciations, spellings, forms, meanings, collocations, etc., of key words and expressions in BE so that students are expected to produce them when they are learning their core modules such as human resource management, marketing, macro economics, micro economics etc. According to my survey, most of the MBA students are fed up with the conventional PPP mode. On the contrary, DDL, which is of the Observe-Hypothesize-Experiment (OHE) mode, can satisfy the requirements of MBA students because the inductive and self-directed language learning of advanced and special use is a must for them. The advantage to this approach is that students are no longer passive recipients of knowledge; instead, they take on more responsibility for their language learning, with the teacher only as a facilitator (Lytovchenko, 2009).

In the DDL approach, students are exposed to a large quantity of authentic language materials in the business context, and they have to predict the common pattern of language use, including the word's part of speech, meaning, and collocations; rather than simply being passive recipients of the word use.

- We will only focus on ten keys words for one session of the BE teaching as this approach needs a lot of time for students to explore in the language.

- These ten words are displayed in a format called "keyword-in-context (KWIC)" - the key word is put in the middle of the sentence and in bold, which is easy to catch students' attention.

- Students have 3 minutes to predict and make hypotheses of the use of one word. Later on some of them are chosen to report their finding to the whole class. It is common that the other students have different ideas about words' use. We have a heated discussion about the usage of the words and if we cannot reach consensus, we consult the dictionary to confirm or reject our hypotheses or prediction of the words use.

The DDL approach, based on the OHE mode, is found effective and very popular with the MBA students as it enables students to be exposed to a large amount of authentic language in the business context and they can acquire the language use in a self-reliant way.

\subsection{Activity 2: Language Points Teaching}

MBA students are usually business executives who have been in the work field for more than five years. They would like to take on more responsibilities in the classroom during the learning process. Presenting them the grammatical rules or language points and requesting them to memorize the rules and points one by one are not suitable for such adult students. The adapted version of Folse's "sentence auction" (2008) activity is helpful for them to become competitive, a quality MBA students usually have. This activity is business-related and make MBA students enthusiastic about the acquisition of sentence structures. 
- Vital sentence structures are selected from the textbook. Then the coining of grammatically-wrong sentences relies on the help of Chinese Learner English Corpus (CLEC). CLEC is a learner corpus which reliably records the inter-language development of a representative group of learners (Gui and Yang, 2003). With the guidance of CLEC, ten sentences, wrong and correct ones, are ready for auction.

- The sentences for auction are displayed on Powerpoint (PPT) slides. There are ten sentences in total, and on each of the slides are two sentences.

- Students are divided into study groups, with four students in each group. They have a discussion about whether they should auction a particular sentence or not before the auction starts. Grouping is not just a convenient way to accumulate the individual knowledge but also a good way for MBA students to form team-work spirit.

- Specially-designed paper money has to be prepared. The bid for each sentence starts at 10 dollars, and they need to add at least 10 dollars for each bid. They have to bear in mind that there is no penalty for "purchasing" wrong sentences. The winning group is the one with the largest number of correct sentences.

- Students are curious about the reasons why some sentences are correct while the others are incorrect. Very often a time, students challenge my explanation of language points and ask for more examples. In doing so, students take on more initiative in the acquisition of language points.

\section{Findings - Feedback from MBA Students}

Each of the questions in the questionnaire is a multiple-choice item which is designed on the basis of Lickert scale: from the most important (weighing 5) to the least important (weighing 1). The data collected have been processed and analyzed by SPSS 19.0 and the analyzed data lead to the following conclusions:

First, questions Q1 and Q2 attempt to find out MBA students' general opinions about DDL: whether they are for or against this method. MBA students are of the following characteristics: first, they have been exposed to the conventional language teaching method for many years and it is quite challenging for them to accept another method; second, most of the students seldom have opportunities to use English in their work and daily life; third, they are mature adults who have been in the work field for many years and they are mature and have a clear idea about their needs. Their feedback is conductive to the development of DDL, providing useful suggestions for the application of DDL in new fields. The statistics of Q1 and Q2 reveal that MBA students hold conservative attitude towards the application of DDL in the BE teaching. Most of the students think the effect of DDL is ordinary, and it has room for improvement. The difference is significant at the 0.05 level (see Table 2). The students, to some extent, agree that DDL is more effective than the conventional method. The difference is significant at the 0.05 level (see Table 2).

Second, questions Q3, Q4, Q5 and Q6 are about DDL's application in students' vocabulary acquisition. Most of the students are not clear about DDL's function in the vocabulary spelling. The difference is significant at the 0.05 level (see Table 2). This finding reveals that more emphasis should be laid on vocabulary spelling when I use the DDL method. Students find DDL is effective in helping them acquire the meaning and usage of the words. The difference is significant at the 0.05 level (see Table 2). It is probably because the words are shown in the KWIC format and in different contexts which enable them to consider words' usage in the English context instead of mechanically memorizing their Chinese equivalents as they usually do in the conventional method. In addition, students find it a useful way for them to expand their vocabulary. The difference is significant at the 0.05 level (see Table 2).

Third, questions Q7 and Q8 are about the effects of DDL on students' improvement of their listening and speaking skills. Statistics reveal that students cannot see some significant improvement in their listening and speaking skills by adopting DDL. The difference is significant at the 0.05 level (see Table 2). The reason may be that students can only read the words shown on the printed handouts, and they are not informed of the words' pronunciation. How we can apply the DDL method in an audio-visual way remains to be seen.

Fourth, questions Q9 and Q10 are about the effects of DDL on students' improvement of their reading and writing skills. Students find the DDL method works effectively in helping them improve their reading and writing skills. The difference is significant at the 0.05 level (see Table 2). Since the students are shown large quantities of authentic language materials, they can associate words with the different contexts in which they can be used accurately.

From the statistics we have found and analyzed, we can safely come to the conclusion that the application of DDL in the MBA program is innovative, and comparatively successful. But it still has room for improvement especially in vocabulary acquisition, and improvement of listening and speaking skills. 
Table 1. Items and scopes of the questionnaire

\begin{tabular}{cl}
\hline Item & Scope \\
\hline Q1 & What do you think of the application of DDL in the MBA program? \\
\hline Q2 & $\begin{array}{c}\text { Do you agree with the following statement: “DDL is more effective in English language } \\
\text { teaching and learning, compared with the conventional method.” }\end{array}$ \\
\hline Q3 & How useful do you think DDL is to your spelling of the words? \\
\hline Q4 & How useful do you think DDL is to your acquisition of the meanings of the words? \\
\hline Q5 & How useful do you think DDL is to your application of the words? \\
\hline Q7 & How useful do you think DDL is to your expanding of vocabulary? \\
\hline Q8 & How useful do you think DDL is to your improvement of speaking skills? \\
\hline Q10 & How useful do you think DDL is to your improvement of reading skills? \\
\hline
\end{tabular}

Table 2. Chi-Square test statistics

\begin{tabular}{cccc}
\hline Item & Chi-Square & Degree of Freedom & Asympotic Significance(2-tailed) \\
\hline Q1 & 24 & 4 & $p<0.05$ \\
\hline Q2 & 16 & 4 & $p<0.05$ \\
\hline Q3 & 16 & 4 & $p<0.05$ \\
\hline Q4 & 37.6667 & 4 & $p<0.05$ \\
\hline Q5 & 17.6667 & 4 & $p<0.05$ \\
\hline Q6 & 33.3333 & 4 & $p<0.05$ \\
\hline Q7 & 29.3333 & 4 & $p<0.05$ \\
\hline Q8 & 21 & 4 & $p<0.05$ \\
\hline Q9 & 48 & 4 & $p<0.05$ \\
\hline Q10 & 11.3333 & 4 & $p<0.05$ \\
\hline
\end{tabular}

\section{Conclusion}

It is no exaggeration to say that MBA students in China frequently have a negative attitude towards the CBEC. Nevertheless, they attend this course because: first, it is usually a compulsory course and they need to obtain the credit to get the degree; second, they are obliged to pass a series of English proficiency exams.

On the other hand, China National MBA Education Supervisory Committee has already realized the importance of the BE course in the internationalization of MBA programs in China. But a designated and detailed syllabus has not been issued till now. How teachers can conduct BE course is still a tough problem to be solved.

From my observation, students have higher motivation in attending the CBEC than before, and they are no longer exam-oriented: they simply enjoy the process of BE acquisition. This pedagogic proposal of using DDL in $\mathrm{BE}$ teaching is not just suitable for the CBEC. It is hoped that my proposal can contribute significantly to the undeniable need to educate MBA students to be more engaging in BE teaching and learning.

\section{References}

China National MBA Education Supervisory Committee. (2011). The syllabus for MBA programs in China. Beijing: China Machine Press.

China National Postgraduate Education Supervisory Committee. (2001). The syllabus of postgraduate English course for non-English majors. Chongqing: Chongqing University Press.

Folse, K. S. (2008). Six vocabulary activities for the English language classroom. English Teaching Forum, 
46(3), 12-21.

Gui, S. C., \& Yang, H. Z. (2003). Chinese learner English corpus. Shanghai: Shanghai Foreign Language Education Press.

Kaufman, D. (2004). Constructivist issues in language learning and teaching. Annual Review of Applied Linguistics,24(3), 303-319. http://dx.doi.org/10.1108/17504971111121919

Lytovchenko, I. (2009). How to make upper-level university English classes more interactive. English Teaching Forum, 47(2), 24-29.

Piaget, J. (1970). The science of education and the psychology of the child. New York: Basic Books.

Piaget, J., \& Inhelder, B. (1971). Psychology of the child. New York: Basic Books.

Salsbury, T., \& Crummer, C. (2008). Using teacher-developed corpora in the CBI classroom. English Teaching Forum,46(2), 28-37.

Schcolnik, M., Kol, S., \& Abarbanel, J. (2006). Constuctivism in theory and in practice. English Teaching Forum,44(4), 12-20.

Vygotsky, L. S. (1986). Thought and language. Cambridge, MA: M.I.T. Press. 